\title{
PEDAGOGICAL CONCEPT \\ OF THE CIVIL SECURITY SPECIALISTS' \\ ADVANCED TRAINING
}

\section{ПЕДАГОГІЧНА КОНЦЕПЦІЯ \\ ПІДВИЩЕННЯ КВАЛІФІКАЦІЇ ФАХІВЦІВ З ПИТАНЬ ЦИВІЛЬНОЇ БЕЗПЕКИ}

\section{Viktor Mykhailov ${ }^{1}$}

DOI: https://doi.org/10.30525/978-9934-26-077-3-14

Abstract. In legal documents of the Ministry of Education and Science of Ukraine, there is emphasized the need to find ways to improve the level of professional knowledge, skills, abilities and new forms of training in educational establishments, which, in its turn, necessitates the transformation of training strategy. The need to respond to dangerous natural, human-made, anthropogenic, epidemiological and social factors requires highly qualified professionals ready to work in extreme conditions. Therefore, the importance of filling existing gaps in the theory and practice of vocational education determines the need for conceptual justification, development and testing of an improved pedagogical system of civil security professionals' advanced training. The paper considers the theoretical foundations of the organization of advanced training of specialists in civil security, summarizes the main problems of professional development within the institutions and educational establishments. The content and features of their professional training in order to ensure the safety of people in emergencies is analyzed as well. It is found out that the readiness of civil security specialists to carry out their professional activities is an individual feature that includes professional motives, a set of special knowledge, skills and abilities of civil security professionals, which in integration ensure their ability to perform professional tasks and provide their further professional development. The author outlines the conceptual provisions for improving the advanced training of civil security professionals in institutions and educational establishments for the formation of positive

\footnotetext{
${ }^{1} \mathrm{PhD}$ in Public Administration, Associate Professor, Institute of Public Administration and Research in Civil Protection, Ukraine

(C) Viktor Mykhailov
} 
motives for educational activities, the appropriate level of professional competence and approaching the ultimate goals of education. The content of the concept of specialists in civil security advanced training is determined (relevant methodological approaches, didactic principles, goals, objectives, pedagogical conditions are outlined as well). The purpose of forming the concept of advanced training of civil security specialists in postgraduate education should be directed towards the individual needs for personal and professional growth, as well as to meet the needs of the state in highly qualified and professional specialists capable of responsible performing of the job functions related to solving problems in order to ensure the safety of life and activities of people. The proposed conceptual framework helps identify the main components of the advanced training system for civil security professionals, resolving a number of contradictions, the main of which is the contradiction between the public demand for highly qualified professionals prepared for the challenges of modern society and the current training system which at present does not fully meet these requirements.

\section{1. Ветуп}

Зміни економічного, політичного та соціального характеру нині вимагають нових підходів та управлінських рішень, адекватних реаліям та міжнародним стандартам безпеки життя і діяльності людей. Нова епоха і глобалізація супроводжується сплеском цілої низки міждержавних конфліктів, тому безпека життя і діяльності людини є об'єктивною потребою. Основні зусилля щодо розвитку сил безпеки України зосереджені на поетапному та узгодженому нарощуванні оперативних спроможностей та рівня їх готовності до невідкладного реагування на виклики і загрози, які постають перед суспільством [1]. Стратегією національної безпеки України, затвердженої Указом Президента України від 14 вересня 2020 року № 392/2020, підтверджується необхідність пошуку шляхів підвищення рівня професійних знань, умінь, навичок фахівців органів сектору безпеки в закладах, установах освіти для забезпечення функціонування державної системи своєчасного виявлення, запобігання і нейтралізації загроз, зокрема, природного та техногенного антропогенного, епідеміологічні, соціального характеру.

У сучасних умовах особливої значущості набуває завдання формування особистісних і професійних якостей фахівців з питань цивільної 
безпеки. Якісно змінюється характер вимог до рівня їх особистої підготовленості та професійної діяльності. Ускладнився характер професійної діяльності цих фахівців при реагуванні на надзвичайні ситуації та пожежі, підвищилася відповідальність при прийнятті рішень. Виникла необхідність оволодіння новими методами роботи щодо керівництва підлеглими в особливих умовах роботи. На фахівців з питань цивільної безпеки покладається широке коло обов'язків не лише з локалізації та ліквідації надзвичайних ситуацій та пожеж, а й із порятунку людей і майна від їх наслідків. Все це вимагає цілеспрямованого, поетапного професійного розвитку фахівців в умовах навчання в закладах, установах освіти, а потім і в ході подальшої професійної діяльності.

Професійний розвиток фахівців, діяльність яких пов'язана з вирішенням завдань 3 питань цивільної безпеки, відповідних заходів для належного захисту та порятунку людей, об'єктів від надзвичайних ситуацій має необхідність розроблення нових підходів і стратегій, що відповідають сучасним запитам суспільства, з урахуванням завдань порядку денного галузі цивільної безпеки. Тим самим, завдання формування особистісно-ділових і професійно-значущих якостей у фахівців 3 питань цивільної безпеки набуває іншого змісту, що вимагає їх невпинного професійного розвитку в процесі виконання посадових обов'язків. Швидкоплинність та ускладнення процесів сучасного життя, із загальною тенденцією до його зростання для кожної окремої людини, об'єктивно визначають потребу в формуванні особистості, здатної сприймати і здійснювати перетворення, налаштованої на усвідомлення змінності світу як природної норми та безперервного підвищення свого компетентнісного рівня [2]. Найбільш гострою проблемою нині є недосконалість механізму визначення освітніх потреб, невідповідність існуючої системи підвищення кваліфікації сучасним вимогам до змісту та якості професійного навчання фахівців, відсутність цілісної системи моніторингу та оцінювання якості надання освітніх послуг.

\section{2. Підготовка фахівців 3 питань цивільної безпеки} в дослідженнях та публікаціях вітчизняних вчених

Проблеми, що пов'язані із удосконаленням системи професійної підготовки фахівців з питань цивільної безпеки, знаходяться в центрі уваги вітчизняних та зарубіжних вчених. Важливими для нашої статті 
є результати наукових досліджень О. Бикової, Н. Вовчастої, П. Волянського, І. Коваля, М. Козяра, Г. Корж, А. Кузика, Є. Литвиновського, Ю. Ненько, К. Пасинчук, О. Повстин, Ю. Таймасова, А. Терент'євої, М. Фомича, М. Кришталя, В. Юрченка, присвячених розкриттю проблем підготовки фахівців для роботи в умовах надзвичайних ситуацій, психолого-педагогічних механізмів професійної підготовки фахівців, вивченню питань їх професійного становлення, окремих питань професійної підготовки співробітників ДСНС України тощо. Обгрунтування окремих концептуальних аспектів вдосконалення професійної підготовки фахівців різних галузей знань здійснювали В. Артюх, О. Анішенко, К. Везетіу, С. Гаркуша, С. Калаур, Г. Кашина, О. Коваленко, М. Коваль, Л. Лук’янова, Н. Ничкало, С. Пінчук, В. Прусак, С. Соколова та інші.

Всі ці роботи сприяли надбанню та систематизації знань за результатами дослідження. Незважаючи на наявність вищевказаних та інших досліджень і віддаючи належне внеску багатьох дослідників відзначимо, що робіт, присвячених системному аналізу підвищення кваліфікації фахівців органів влади (підприємств, установ, організацій), діяльність яких пов'язана 3 реалізацією заходів цивільної безпеки, спрямованих на розвиток необхідних професійних навичок і особистісних якостей, нами виявлені фрагментарно. У науковій літературі не знайшли свого відбиття питання, пов'язані з розробкою педагогічної концепції удосконалення системи підвищення кваліфікації фахівців 3 питань цивільної безпеки для ефективного формування їх особистісних та професійних якостей.

\section{3. Основні протиріччя, що впливають на якість} професійної діяльності фахівців 3 питань цивільної безпеки та визначають актуальність нашого наукового дослідження

Аналіз психолого-педагогічної літератури дозволяє нам зробити висновок, що формування професійних і особистісних якостей у фахівців з питань цивільної безпеки є важливим етапом на шляху їх розвитку як професіонала, здатного творчо застосовувати свої знання, уміння та навички в професійній діяльності.

На основі вивчення досвіду професійної підготовки фахівців 3 питань цивільної безпеки, аналізу психолого-педагогічної та науко- 
во-методичної літератури було виявлене і сформульоване завдання дослідження стосовно розробити педагогічної концепції вдосконалення системи підвищення кваліфікації фахівців 3 питань цивільної безпеки, яке обумовлене суперечностями між:

потребою органів влади (підприємств, установ, організацій) в кваліфікованих, професійно-компетентних фахівцях і недостатнім рівнем їх професійної підготовленості;

необхідністю підвищення ефективності процесу підвищення кваліфікації фахівців з питань цивільної безпеки в умовах закладів, установ освіти і недостатньою розробленістю програмно-методичного забезпечення даного процесу;

необхідністю підвищення рівня розвитку професійних і особистісних якостей у фахівців з питань цивільної безпеки в процесі підвищення кваліфікації і відсутністю методичних рекомендацій щодо їх формування.

Потреба у вирішенні зазначених протиріч визначає актуальність нашого дослідження. Наявність зазначених протиріч потребує побудови педагогічної концепції системи підвищення кваліфікації фахівців 3 питань цивільної безпеки до дій в надзвичайних ситуаціях природного, техногенного, антропогенного, епідеміологічного, соціального характеру та пожеж.

\section{4. Передумови вдосконалення системи підвищення кваліфікації фахівців з питань цивільної безпеки}

Провідною ідеєю організації та розвитку європейської освіти у XXI столітті стала філософсько-педагогічна концепція неперервної освіти, як пролонгований вид діяльності дорослого населення. Таке навчання спрямоване на здобування нових та розвиток набутих знань, умінь, навичок і якостей особистості, поглиблення та зміцнення іiї світогляду і ціннісної орієнтації, розкриття всіх можливостей в мінливих соціально-економічних умовах, містить в собі, зокрема, різноманітні форми та види освіти дорослих, межі якої визначаються принципами андрагогіки.

Серед сучасних концепцій освіти, що пов'язані зі світовими тенденціями, однією з найважливіших в Україні є концепція післядипломної освіти, спрямована на розвиток отриманих і здобування нових знань, умінь, навичок особистості, розкриття всіх їі можливостей. В освітніх 
документах нашої країни (Закон України «Про освіту», Закон України «Про вищу освіту», Державна національна програма «Освіта» (Україна XXI століття), Національна доктрина розвитку освіти, Концепції розвитку освіти України та інші), які розкривають зміст післядипломної освіти, ставиться завдання розвитку актуальних професійних компетентностей особи, необхідних для іiї успішної професійної діяльності.

Післядипломна освіта забезпечує здобуття нової кваліфікації, нової спеціальності на основі раніше здобутого рівня освітньої та професійної підготовки, а також набутого практичного досвіду, самостійного навчання людини незалежно від віку. Важливість навчання фахівців в галузі цивільної безпеки завжди виявлялася на переломних етапах розвитку економіки країни, в якій бачили одну з реальних сил, що забезпечує безпечне життя і діяльність людини. Сучасні програмні документи, що визначають аспекти навчання фахівців 3 питань цивільної безпеки, позбавлені попередніх прорахунків, хоча і містять цілісну картину проблемних питань і необхідності їх подальшого удосконалення. Базова професійна освіта фахівців з питань цивільної безпеки забезпечує сформованість інтелектуальних якостей, що обумовлюють розвиток для здобуття ними кваліфікації, тоді, відповідно до значення післядипломної освіти, сутність підвищення кваліфікації фахівців 3 питань цивільної безпеки визначаємо як спеціалізоване навчання для вдосконалення, поглиблення, розширення та оновлення їх професійних знань, умінь і навичок. У цьому контексті післядипломна освіта в галузі цивільної безпеки набуває якісної визначеності та спрямована на професійний розвиток фахівця, його професійно-особистісне самоутвердження. Невід'ємною складовою цього $є$ розбудова ефективної системи підвищення кваліфікації фахівців з питань цивільної безпеки, визначення пріоритетів і напрямів їх професійного розвитку, а також розроблення відповідної концепції.

Нинішній персонал галузі цивільної безпеки характеризується розмаїттям як освітньо-кваліфікаційних рівнів, так і напрямів підготовки та спеціальностей, за якими здобули освіту фахівці з питань цивільної безпеки, який можна згрупувати за наступними рівнем і напрямом освіти:

випускники закладів вищої освіти Державна служба України з надзвичайних ситуацій за ступенями вищої освіти «молодший спеціаліст», «бакалавр», «магістр». Тобто особи, які отримали спеціальну вищу 
освіту, спрямовану на професійну діяльність 3 питань цивільної безпеки в підрозділах оперативно-рятувальної служби цивільного захисту [3];

випускники закладів вищої освіти за першим (бакалаврським) рівнем вищої освіти в галузі знань 26 - Цивільна безпека, спеціальність 263 - Цивільна безпека (освітня кваліфікація - бакалавр з цивільної безпеки), здатні виконувати професійні роботи за відповідними професіями, а саме: «Фахівець $з$ піротехнічних, саперних та підривних робіт», код КП 3117; «Черговий оперативний (загону, центрального командно-диспетчерського пункту, оперативно-рятувальної служби цивільного захисту та ін.)», код КП 3119; «Інспектор державний 3 питань цивільного захисту та техногенної безпеки», код КП 3449; «Фахівець $з$ радіаційного та хімічного захисту», код КП 3439; «Фахівець оперативно-рятувальної служби цивільного захисту», код КП 3439; «Інспектор з охорони праці», код КП 3152 [4; 5];

випускники закладів вищої освіти за другим (магістерським) рівнем вищої освіти в галузі знань 26 Цивільна безпека, спеціальність 263 Цивільна безпека (освітня кваліфікація - магістр з цивільної безпеки за спеціалізацією), здатні виконувати професійні роботи за відповідними професіями, а саме: «Начальник оперативного відділу (сфера цивільного захисту)», код КП 1229.7; «Начальник підрозділу оперативно-рятувальної служби з профілактичних заходів цивільного захисту», код КП 1229.7; «Командир (начальник) підрозділу (сфера цивільного захисту)», код КП 1239; «Командир (начальник) частини (сфера цивільного захисту)», код КП 1239; «Командир загону (сфера цивільного захисту)», код КП 1239; «Інженер з піротехнічних, саперних та підривних робіт», код КП 2147.2; «Інженер з аварійно-рятувальних робіт», код КП 2149.2; «Інженер оперативнорятувальної служби цивільного захисту», код КП 2149.2; «Інженер 3 охорони праці», код КП 2149.2; «Експерт технічний $з$ промислової безпеки», код КП 2149.2; «Страховий експерт з охорони праці», код КП 2412.2; «Експерт 3 умов праці», код КП 2412.2; Молодший науковий співробітник (галузь інженерної справи), код КП 2149.1; «Науковий співробітник (галузь інженерної справи)», код КП 2149.1. 3152 [4; 6];

діючі особи керівного складу та фахівці центральних органів виконавчої влади, місцевих держадміністрацій, органів місцевого самоврядування, суб'єктів господарювання, які не мають спеціальної освіти, 
спрямованої на професійну діяльність в галузі цивільної безпеки, проте перебувають на посадах, обов'язки яких передбачають організацію і здійснення заходів з питань цивільного захисту.

Ураховуючи чинні вимоги на посади фахівців з питань цивільної безпеки в кожній галузі економіки мають призначатись особи, які мають відповідні за фахом знання та уміння і документ державного зразка, який підтверджує отримання особою професійних знань в конкретній галузі. Проте, в багатьох центральних та місцевих органах виконавчої влади, органах місцевого самоврядування та суб' єктах господарювання відсутні фахівці, які мали б професійну підготовку в галузі «Цивільна безпека», на посадах, що передбачають виконання обов' язків з питань цивільної безпеки. Такі фахівці, в кращому випадку, мають фахову підготовку у військовій або інженерно-технічній галузі. Зазначені особи у період перебування на посаді, відповідно до вимог чинних нормативно-правових актів [7], проходять підвищення кваліфікації в Інституті державного управління та наукових досліджень 3 цивільного захисту (для потреб центральних органів виконавчої влади) та на базі навчально-методичних центрів цивільного захисту та безпеки життєдіяльності і територіальних курсів цивільного захисту та безпеки життєдіяльності областей, м. Київ (для потреб місцевих органів виконавчої влади, органів місцевого самоврядування, суб'єктів господарювання).

\section{5. Структура і закономірності, властиві процесу підвищення кваліфікації фахівців 3 питань цивільної безпеки}

Короткий аналіз відповідності рівня і напряму освіти фахівців 3 питань цивільної безпеки в органах влади (підприємствах, установах, організаціях) не передбачає можливості схарактеризувати існуючий стан їхньої підготовленості та запропонувати заходи щодо його покращання. Проте, в системі підвищення кваліфікації цих фахівців важливим $є$ перегляд змісту навчання, як головного фактору, який визначає аспекти навчального процесу (засоби, методи, форми та інше). У цьому випадку завдання полягає в тому, щоб зміст підвищення кваліфікації фахівців з питань цивільної безпеки грунтувався на технологіях, що стимулюють інтерес фахівців до теоретичних знань та практичного досвіду, сприяють набуттю ефективних способів вирішення 
фахових проблем, охоплюють широкий спектр професійного навчання 3 поєднанням теоретичного матеріалу із практичною спрямованістю вирішення конкретних завдань безпеки людей.

Запропонований нами зміст теоретичних занять підвищення кваліфікації фахівців з питань цивільної безпеки за загальним (вивчення нормативно-правових вимог держави щодо побудови та забезпечення діяльності державної системи своєчасного виявлення, запобігання $\mathrm{i}$ нейтралізації загроз природного та техногенного антропогенного, епідеміологічні, соціального характеру, оновлення й вдосконалення знань про сутність, функції та основні заходи з реалізації завдань щодо запобігання і реагування на надзвичайні ситуації різного походження), диференційованим (опанування фахівцем технологій (алгоритмів) вирішення основних завдань відповідно до його функцій та обов'язків за посадою в рамках відповідної підсистеми єдиної державної системи цивільного захисту), регіональним (здобуття знань та умінь для виконання завдань 3 питань цивільної безпеки із урахуванням усіх небезпек природного і техногенного походження окремого регіону) та місиевим (здобуття практичних умінь навичок для успішного виконання завдання з реагування на надзвта пожежі ичайні ситуації на певній території (об’єкті), організації відновлювальних робіт) компонентами програми підвищення кваліфікації повинен розкриватись в їх змістовних модулях. Кожен з цих модулів складається 3 певного обсягу навчальної інформації, яка повинна відповідати сучасному розвитку теорії і практики цивільної безпеки, завданням з цивільної безпеки певної галузі економіки, розкривати алгоритми їх реалізації.

Практичні заняття на навчальних об'єктах проводяться 3 метою формування умінь і навичок у фахівців працювати з планувальними, обліковими та звітними документами, обладнанням, технічними засобами, спеціальним спорядженням та майном цивільного захисту. Під час проведення загальнодержавних, регіональних і місцевих командно-штабних, штабних та спеціальних об'єктових навчань і тренувань фахівці закріплюють теоретичні знання та набувають практичних навичок і досвіду для виконання відповідних завдань та функцій за посадою, яка пов'язана з виконанням завдань 3 питань цивільної безпеки в органі влади (підприємстві, установі, організації) [8]. 
Відправною точкою при розробці програм підвищення кваліфікації фахівців має бути чітке визначення очікуваних результатів навчання. Показниками сформованості компетентності фахівців з питань цивільної безпеки до виконання функціональних обов'язків в межах своїх повноважень $є$ рівень: знань нормативно-правової бази щодо дій у надзвичайних ситуаціях;

умінь і навичок з виконання завдань 3 питань цивільної безпеки в межах функціональних обов'язків;

відповідальності та автономності у виконанні покладених завдань 3 розв'язання проблем із запобігання надзвичайним ситуаціям, готовності до реагування на них та вжиття заходів щодо усунення або мінімізації їх наслідків;

здатності на конструктивну взаємодію з іншими посадовими особами в межах виконання функціональних обов'язків.

Основними етапами діагностики результатів підвищення кваліфікації фахівців з питань цивільної безпеки є:

чітке усвідомлення і постановка цілей підвищення кваліфікації;

добір і розробка відповідних методичних матеріалів підвищення кваліфікації; визначення об'єктів вивчення;

вивчення професійних компетентностей фахівців перед початком навчання («вхідний тестовий контроль»);

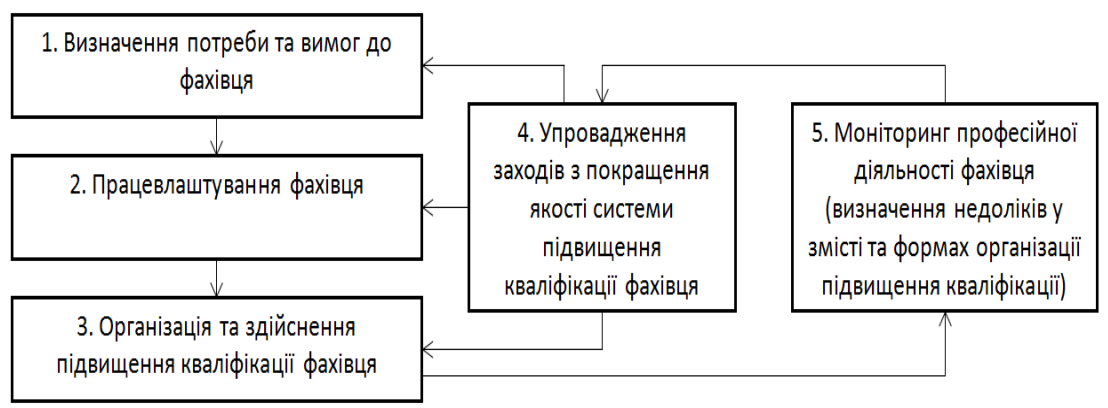

Рис. Система управління якістю закладу, установи освіти у взаємодії із замовником щодо підвищення кваліфікації фахівців 3 питань цивільної безпеки

Джерело: авторська розробка 
під час проведення навчальних занять здійснюється поточний контроль, який має на меті перевірку рівня підготовленості фахівців до виконання конкретного завдання, роботи;

вивчення рівня професійних компетентностей фахівців на завершальному етапі підвищення кваліфікації («підсумковий тестовий контроль»).

В нагоді могли б стати ініційовані на основі стандартів ISO серії 9000 закладами, установами освіти, у взаємодії із замовниками навчання, модель управління якістю підвищення кваліфікації фахівців 3 питань цивільної безпеки (рис.)

\section{6. Характеристика концептуальних засад,} які визначають ефективність функціонування системи

\section{підвищення кваліфікації фахівців 3 питань цивільної безпеки}

Отже, зміст підвищення кваліфікації фахівців вимагає чіткого формулювання опису його структури, має уможливити їх подальший розвиток та професійне мислення, динамізм в прийнятті рішень та вміння реалізовувати означене в професійній діяльності. Це означає необхідність проектування концептуальних засад підвищення кваліфікації фахівців з питань цивільної безпеки до професійної діяльності, що дає змогу чітко визначити мету і завдання цього навчання, сформувати іiі загальну методику, виділити ключові методи тощо.

Педагогічні системи створюються з урахуваннями освітньої мети, яка в свою чергу, відображає сукупність суспільних вимог та запитів до рівня професійної готовності фахівця з питань цивільної безпеки та $є$ іманентним описом змісту підвищення кваліфікації, оскільки у ньому мета педагогічно вдосконалюється та конкретизується. Цілі професійного розвитку фахівців з питань цивільної безпеки тісно пов'язані з мотивацією особистості, оскільки формування професійних компетентностей у здійсненні ними професійної діяльності $є$ водночас освітнім і особистісним процесом, внаслідок чого відбуваються зміни на рівні вдосконалення професійних знань, умінь і навичок, трансформація інтересів, потреб і мотивів.

На наш погляд, концепцією підвищення кваліфікації фахівців 3 питань цивільної безпеки до професійної діяльності є базовий задум $з$ реалізації цього навчання, сукупність положень наукових теорії, парадигм, що використані з метою отримання оптимального науково-прак- 
тичного результату. У дослідженні ми виходимо з того, що концепція формування готовності фахівців до професійної діяльності грунтується на положеннях педагогічної науки, закономірностях і принципах розвитку особистості, які взаємопов'язані між собою і структуруються на методологічному, теоретичному і технологічному рівнях, реалізується поетапно, з урахуванням рівнів і змісту навчання.

Узагальнюючи міркування науково-теоретичних основ педагогічного процесу сформулюємо авторські ідеї підвищення кваліфікації фахівців з питань цивільної безпеки в умовах післядипломної освіти, які, за нашим задумом, мають визначати певні наріжні аспекти:

1. Оскільки підвищення кваліфікації з питань цивільної безпеки $\epsilon$ різновидом андрагогіки, таке навчання реалізує основні положення освіти дорослих, де фахівці відіграють провідну роль у власному удосконалені знань, заснованих на їх природному прагненні до саморозвитку; базується на індивідуальних освітніх потребах та стимулюється їх зростанням, що стає запорукою успішності в професійній діяльності.

2. Диверсифікація змісту навчання фахівців з питань цивільної безпеки має на меті запровадження навчальних технологій, які повинні забезпечити здійснення різних варіантів навчальних програм щодо розвитку фахівців нової генерації в галузі цивільної безпеки.

3. Особистісний потенціал фахівців з питань цивільної безпеки, який розвивається в умовах післядипломної освіти, стає підгрунтям набуття професійно-орієнтованих практичних навичок для реагування на надзвичайні ситуації та пожежі з метою захисту населення і територій, проведення відновлювальних робіт.

4. Процес підвищення кваліфікації фахівців з питань цивільної безпеки базується на активній спільній діяльності тих, хто навчає, 3 тими, хто навчається. Науково-педагогічні працівники в умовах такої взаємодії з фахівцями проявляють сприяння та співпрацю із застосуванням новітніх інформаційно-комунікаційних технологій навчання.

5. Під час забезпечення високої якості проведення занять особлива увага науково-педагогічними працівниками закладів, установ освіти зосереджується на врахуванні вимог замовників навчання щодо виконання фахівцями функцій за посадою в органі влади (підприємстві, установі, організації). Для вдосконалення педагогічної майстерності 
науково-педагогічних працівників, які здійснюють навчання фахівців 3 питань цивільної безпеки, адаптованого до змін в сучасному розвитку освіти, має запроваджуватись стажування в органах управління та підрозділах ДСНС України.

6. Керівники територіальних підсистем (ланок) державної системи своєчасного виявлення, запобігання і нейтралізації загроз природного та техногенного антропогенного, епідеміологічні, соціального характеру провадять освітні стратегії для набуття та систематичного оновлення фахівцями 3 питань цивільної безпеки практичних умінь і навичок в ході підготовки та проведення командно-штабних, штабних та спеціальних об'єктових навчань і тренувань 3 питань цивільної безпеки за економічних, фізико-географічних та інших особливостей адміністративної території (об'єкту) проведення тренування, імовірності виникнення надзвичайних ситуацій та пожеж, наявності можливостей для здійснення заходів захисту населення від їх наслідків.

7. Моніторинг рівня сформованості готовності до професійної діяльності фахівців з питань цивільної безпеки здійснюється з урахуванням поглядів, зацікавленості і відповідних дії замовників навчання, спрямованих на підтримку й розвиток освітніх послуг закладами, установам освіти.

Пошук способів проектування теоретичного та методологічного фундаменту підвищення кваліфікації фахівців з питань цивільної безпеки до їх професійної діяльності передбачає врахування нами того, що методи, форми, засоби та прийоми їх навчання перевірені часом та практикою і є основою для успішної підготовки не одного покоління кадрів для галузі цивільної безпеки. На різних етапах свого становлення та розвитку система професійної підготовки фахівців була визнана ефективною та продуктивною.

3 огляду на вищевикладене, підвищення кваліфікації фахівців 3 питань цивільної безпеки в закладах, установах освіти зумовлює об'єктивну потребу вибору андрагогічного, акмеологічного, системного, особистісно-діяльнісного, контекстного підходів, які мають скласти основу відповідної концепції. На думку автора, методологічні підходи відображають дослідницьку стратегію розвитку професійних компетентностей фахівців з питань цивільної безпеки, орієнтованої на особистість фахівця і розвиток його професійних якостей, які підви- 
щують мотивацію в професійній діяльності та формують прагнення до самовдосконалення. У поєднанні ці підходи забезпечують розвиток компонентів професійної готовності у фахівців з питань цивільної безпеки, включаючи мотиваційний (професійні мотиви, інтереси, потреби), ціннісний (професійно-ціннісні орієнтації), інформаційний (сукупність спеціальних знань), психологічний (морально-психологічні та професійно важливі властивості) та операційний (професійні практичні уміння і навички). Реалізація цих підходів передбачатиме схвалення та втілення нової навчальної програми, педагогічних технологій в навчальний процес, обмін досвідом (стажування) науково-педагогічних працівників, стимулювання діяльності замовників навчання фахівців з питань цивільної безпеки.

Технологічний рівень концепції розкриває етапи, технологію та послідовність впровадження педагогічних умов, а також інноваційного змісту, форм, методів, особливостей використання засобів розвитку та діагностики готовності фахівців з питань цивільної безпеки до професійної діяльності [9]. Ми виходимо з того, що розвиток готовності цих фахівців до професійної діяльності має здійснюватись поетапно (основний, поглиблений, інтеграційний етапи), з урахуванням рівнів і змісту навчання, а також особливостей професійного розвитку, практичної підготовки, навчального процесу в закладах, установах освіти.

Так, основний етап формування готовності фахівців 3 питань цивільної безпеки охоплює період навчання в закладі вищої освіти, де відбувається активізація впливу на мотиваційний, ціннісний, інформаційний, психологічний, вольовий, оціночний компоненти їх готовності до професійної діяльності.

Етап поглибленої підготовки фахівців, які перебувають на посадах, пов'язаний з виконанням завдань $з$ питань цивільної безпеки, спрямований на формування інформаційного, особистісного, когнітивного компонентів та охоплює курсове навчання фахівців без відриву від виробництва, що передбачає вивчення теоретичного матеріалу та проходження практичної підготовки у складі навчальних груп.

Інтеграційний етап спрямований на формування змістовно-процесуального, мотиваційно-цільового, практичного, операційного компонентів готовності фахівців, що відбувається у період підготовки і проведення спеціальних об' єктових навчань і тренувань, які передба- 
чають відпрацювання практичних дій за планами реагування на надзвичайні ситуації та пожежі.

Формування готовності фахівців до професійної діяльності буде ефективним за впровадження певних умов, які реалізуються впродовж зазначених етапів. Педагогічні умови підвищення кваліфікації фахівців $з$ питань цивільної безпеки - це сукупність спроектованих факторів, що впливають на зовнішні та внутрішні обставини навчального процесу, що забезпечують цілісність підготовки фахівців до професійної діяльності в навчальному середовищі закладу, установи освіти відповідно до вимог держави і суспільства щодо забезпечення життя та діяльності людей.

Реалізація вищезазначених концептуальних засад, в основі якої лежать базові принципи післядипломної освіти (орієнтації на загальнолюдські цінності та ідеали гуманізму; ефективності, безперервності, усвідомленості навчання; опори на досвід того, хто навчається; діагностичності та актуалізації результатів; системності в професійному розвитку; відповідності державним вимогам та освітнім стандартам), є однією з умов задоволення індивідуальних потреб в особистісному та професійному зростанні фахівців з питань цивільної безпеки, а також забезпечення потреб держави в кадрах з високим рівнем професійних компетентностей.

\section{7. Одержані результати}

Підсумовуючи, хотілося б зазначити, що на сучасному етапі розвитку нашої країни з об'єктивних причин професійні компетентності фахівців галузі цивільної безпеки зазнають бурхливого розвитку і пильної уваги з боку держави. А отже, концептуальні засади підвищення кваліфікації фахівців з питань цивільної безпеки визначають окремі компоненти цілеспрямованої, динамічної системи теоретико-методологічних знань про об'єкт дослідження. Таким чином, розроблена педагогічна концепція вдосконалення системи підвищення кваліфікації фахівців з питань цивільної безпеки забезпечує вирішення завдань формування особистісних якостей і здатності адаптуватися до нових умов професійної діяльності. Як свідчать проведені дослідження, ефективність розробленої педагогічної концепції вдосконалення системи підвищення кваліфікації фахівців з питань цивільної безпеки визначається якістю їх підготовки. 


\section{8. Висновки}

Практика професійної діяльності вимагає вирішення завдання щодо розвитку фахівців 3 питань цивільної безпеки, які прагнуть до постійного вдосконалення професійної майстерності та мають високий ступінь адаптивної та професійної мобільності. Відповідно до цього, потреба у високопрофесійних фахівцях галузі цивільної безпеки об'єктивно зростає. Розвиток високопрофесійних навичок та особистісних якостей в процесі професійного навчання цих фахівців набуває першочергового значення.

Процес підготовки фахівців 3 питань цивільної безпеки складний, суперечливий, багатоступінчастий, на якого впливають найрізноманітніші чинники - внутрішні і зовнішні, об'єктивні і суб'єктивні, довготривалі і ситуативні, тому в цьому процесі відмінну особливість виявляються різні закономірності. В основі досліджуваної концепції простежується думка про можливість створення необхідних обставин для вдосконалення системи підвищення кваліфікації фахівців з питань цивільної безпеки, впровадження сучасних альтернативних моделей ïх безперервного професійного та особистісного розвитку як ключової умови реалізації державної політики в галузі цивільної безпеки. Все ж, зазначене вказує на те, що представлені в статті концептуальні засади підвищення кваліфікації фахівців з питань цивільної безпеки не вичерпують всіх аспектів вирішення поставленого завдання, це тільки частина тієї великої роботи, яку потрібно проводити закладами, установами освіти для створення сучасної ефективної системи підвищення кваліфікації фахівців з питань цивільної безпеки.

\section{Список літератури:}

1. Про національну безпеку України : Закон України 21.06.2018 № 2469. Відомості Верховної Ради від 03.08.2018, № 31 .

2. Лук'янова Л.Б. Концепція освіти дорослих в Україні / Лариса Борисівна Лук’янова. - м. Ніжин, ПП Лисенко М.М., 2011. - 24 с.

3. Аналітичний огляд стану техногенної та природної безпеки в Україні за 2018 рік [Електронний ресурс] // УкрНДІЦЗ. - 2018. - Режим доступу: www.dsns.gov.ua (дата звернення: 24.04.2021).

4. Класифікатор професій ДК 003:2010 : Наказ Держспоживстандарт України від 28.07.2010 № 327.

5. Про затвердження стандарту вищої освіти за спеціальністю 263 «Цивільна безпека» для першого (бакалаврського) рівня вищої освіти» : Наказ МОН України від 29.10.2018, № 1170. 
6. Про затвердження стандарту вищої освіти за спеціальністю 263 «Цивільна безпека» для другого (магістерського) рівня вищої освіти» : Наказ МОН України від 22.10.2020, № 1291.

7. Порядок проведення навчання керівного складу та фахівців, діяльність яких пов'язана з організацією і здійсненням заходів з питань цивільного захисту : Постанова Кабінету Міністрів України від 23.10.2013, № 819.

8. Положення про організацію навчального процесу з функціонального навчання : Наказ МВС України від 21.10.2014, № 1112.

9. Даніленко О.Б. Концепция формирования готовности будущих судоводителей кпрофессиональной деятельности / Олександр Борисович Даніленко. // Научен вектор на Балканите. «Научен хронограф» ЕООД: България. Том 3. № 4(6) - 2019. - C. 30-33. DOI: 10.34671/SCH.SVB.2019.0304.0007

\section{References:}

1. On the national security of Ukraine № 2469 (2018, June 21). Vidomosti Verkhovnoi Rady Ukrayiny, 31, 241. (in Ukrainian)

2. Lukianova, L.B. (2011) Kontseptsiia osvity doroslykh v Ukraini [The concept of adult education in Ukraine]. Nizhyn: PP Lysenko M.M. (in Ukrainian)

3. Analitychnyi ohliad stanu tekhnohennoi ta pryrodnoi bezpeky v Ukraini za 2018 rik (2018) (electronic journal) [Analytical review of the state of technogenic and natural security in Ukraine in 2018]. UkrNDITsZ. Retrieved from: www.dsns.gov.ua (accessed 24 April 2021).

4. Klasyfikator profesii DK 003:2010 (2010, July 28) [Classifier of professions DK 003: 2010]: Nakaz Derzhspozhyvstandart Ukrainy. (in Ukrainian)

5. About the statement of the standard of higher education on a specialty 263 «Civil safety» for the first (bachelor's) level of higher education» № 1170 (2018, October 29): Nakaz MON Ukrainy. (in Ukrainian)

6. About the statement of the standard of higher education on a specialty 263 «Civil safety» for the second (master's) level of higher education» (2020, October 22): Nakaz MON Ukrainy. (in Ukrainian)

7. The order of training of management and specialists whose activities are related to the organization and implementation of measures for civil protection № 819 (2013, October 23): Postanova Kabinetu Ministriv Ukrainy.

8. Regulations on the organization of the educational process of functional learning № 1112 (2014, October 21): Nakaz MVS Ukrainy.

9. Danilenko O.B. (2019) Kontseptsyia formyrovanyia hotovnosty budushchykh sudovodytelei k professyonalnoi deiatelnosty [Concept of formation of readiness of future navigators for professional activity]. Nauchen vektor na Balkanyte. «Nauchen khronohraf» EOOD: Bblharyia, vol. 3, 4(6), 30-33. DOI: 10.34671/ SCH.SVB.2019.0304.0007 (in Ukrainian) 